\title{
The Evolution of the Seine Basin Water Bodies Through Historical Maps
}

\author{
Laurence Lestel, David Eschbach, Michel Meybeck, and Frédéric Gob
}

\begin{abstract}
Contents

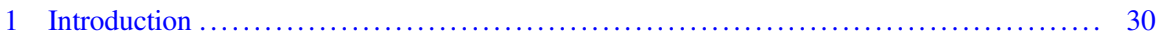

2 The Physical Anthropogenic Transformation of the Seine River (1800-2010) .......... 31

2.1 Transformations of Seine Water Bodies in the Early 1800s and Their Drivers ....... 31

2.2 Current State of the Seine River Water Bodies .......................... 34

3 Historical Maps: A Tool for Quantifying the Physical Changes of Water Bodies ......... 36

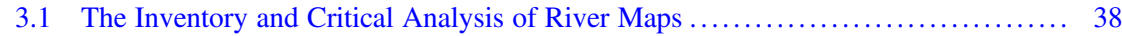

3.2 General Use of Maps to Document River Environmental Changes ............... 40

4 Historical Trajectories of Selected Water Bodies in the Seine River Basin ............. 45

4.1 Stream Network Modification on the Versailles-Saclay Plateau (1670-1860) ...... 46

4.2 Man-Made Heterogeneity of the Floodplain: Channelisation and Sandpits

in the Bassée Floodplain ............................................ 47

4.3 Simplification of Seine River Channel and Loss of Islands ..................... 50

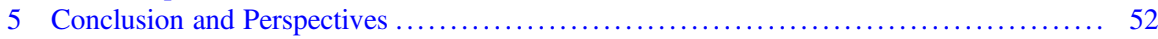

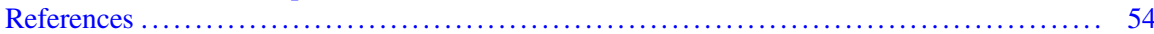

\begin{abstract}
The Seine River basin $\left(65,000 \mathrm{~km}^{2}\right)$ is extremely rich in cartographic documents generated over the past two centuries: general maps describing the territory, fiscal land registries, navigation charts (e.g. bathymetric profiles and maps), etc. After 1830 river engineers (Ponts et Chaussées) started to develop a huge network of waterways, which were charted with precision and accuracy. These documents, retrieved from various archives, have been checked, selected, geo-referenced and digitalised within an open-access database (ArchiSeine). It has allowed researchers to fully quantify the state of rivers, often in their lateral, longitudinal and vertical dimensions, their long-term and slow natural dynamics
\end{abstract}

The copyright year of the original version of this chapter was corrected from 2019 to 2020 . A correction to this chapter can be found at https://doi.org/10.1007/698_2020_667

L. Lestel ( $₫)$, D. Eschbach, and M. Meybeck

Sorbonne Université, CNRS, EPHE, UMR Metis, Paris, France

e-mail: laurence.lestel@ sorbonne-universite.fr

F. Gob

Université Paris 1 Panthéon Sorbonne, Laboratoire de Géographie Physique, Meudon, France

Nicolas Flipo, Pierre Labadie, and Laurence Lestel (eds.), The Seine River Basin,

Hdb Env Chem (2021) 90: 29-58, https://doi.org/10.1007/698_2019_396,

(C) The Author(s) 2020, corrected publication 2020, Published online: 3 June 2020 
(e.g. meander movement) and their abrupt modifications by man-made river works due to various and evolving river use (water supply, wood rafting, navigation, hydropower, sand extraction, flood protection), all closely connected to Paris growing demands, and the adjustments of the fluvial system to these changes. From headwaters to the estuary, the physical attributes of the Seine River system have been substantially modified. Examples of such environmental trajectories are provided for the Versailles plateau headwaters, the Bassée alluvial plain and the Lower Seine sector.

Keywords Environmental trajectories, Geo-history, Historical maps, Secular evolution, Waterbodies

\section{Introduction}

Rivers and their physical evolution are prime examples of the longue durée (multisecular) spatial evolution of the environment, particularly as concerns the hydromorphology of the fluvial system - the river channel(s) and the floodplain at the maximum flood stage [1], ecology [2] and the river landscape [3].

More recently river management and restoration operation have also considered the historical evolution of the fluvial system [4], for instance, to restore the ecological continuity or to take regulatory measures to face extreme events such as droughts and floods. To achieve these objectives, historical data, textual and cartographic, have been increasingly developed since the 1960s. This has been facilitated over the last three decades by the new geographic information system (GIS) techniques and the digitalisation of maps, which allows the analysis of selected cartographic elements represented on a given map, and the comparison of maps, which makes it possible to evaluate spatial dynamics [5-8].

Historical cartographic documents have already been analysed for environmental purposes on many European fluvial systems such as the Po [9], the Rhône [10], the Danube [11] and the Rhine [12]. This approach has also been used by river historians [13-16] and to compare the river-city relations for four main European cities (Paris, Brussels, Berlin and Milan) [17].

In natural conditions, numerous factors may change the hydrology and hydromorphology of rivers, which in turn have an impact on the river hydraulics and on sediment transport, including the floodplain [18, 19]. The response of the fluvial system to historical man-made changes is less known. In many contemporaneous environmental studies, focused on annual to decadal time scales, the slow secular river evolution is not taken into account: the physical attributes of the river are considered invariant, particularly as concerns the river morphology, and the past natural- or human-induced transformations of the system are not considered. Actually the Seine River system has been gradually modified since the Middle Ages, particularly between the mid-1800s and the 1970s for navigation purpose, from the headwaters to the estuary [20], by sand and gravel extraction in alluvial plains [21] and evolving floodplains and wetlands [22]. 
Our objectives here were to illustrate the secular evolution of the Seine River and its related water bodies in order to quantify the trajectories of their physical evolution in their triple dimension - longitudinal, transversal and vertical - based on historical maps. Herein the trajectories are considered as the combination of (1) a set of quantified indicators of changes, natural, man-made or both and (2) the analysis of the historical causes and the context of these changes.

The first section of the chapter is a general overview of the multiple river uses in the Seine basin and the related man-made physical transformations of water bodies, from the headwaters to the estuary. Then we present the historical cartographic sources and the methodology that have been developed to transform them into GIS databases. In the last section we present a selection of trajectories in headwater streams, a river floodplain and the Seine River channel, based on cartographic archives covering the last 200 years.

\section{The Physical Anthropogenic Transformation of the Seine River (1800-2010)}

The river hydrological network is schematised here using the Strahler representation of stream orders, from the first permanent headwater streams (stream order 1) to the mouth of the Seine River (stream order 7) (Fig. 1). The stream order increases when two streams of similar $n$ orders meet to form a $n+1$ order. In the Seine basin, the 5,610 stream order 1 rivers are on average $0.07 \mathrm{~m}$ deep and $1.76 \mathrm{~km}$ long and drain $5.7 \mathrm{~km}^{2}$ [23]. These parameters reach their maximum values for the $438-\mathrm{km}-\mathrm{long}$ Seine River from its confluence with the Yonne River to the sea (stream order 7). We have considered two schematic pictures of the basin, one around 1800 and the other represents the contemporary period (2010s).

\subsection{Transformations of Seine Water Bodies in the Early 1800s and Their Drivers}

Before the French Revolution, the river basin was already somehow affected by human activities (Fig. 1, upper part).

In agricultural land, the headwater network was not significantly modified (Fig. 1a). However, in the headwaters of the forested Morvan mountainous massif (Yonne tributary headwaters, altitude 600-900 m), many medium-sized ponds $(<3 \mathrm{ha})$ regulated water reservoirs for timber rafting. High flows were generated in November to allow the transportation of "free" logs, $1.14 \mathrm{~m}$ long, from the Morvan to the city of Clamecy, where they were stored for several months and eventually assembled and released downstream as 36- then 72-m-long rafts by the spring high flows. This usage had a considerable effect on rivers, due to bank erosion and regular high discharges [24]. Timber rafting, which started in the sixteenth century, was generated by Paris's demand for construction and fuel wood, peaked 

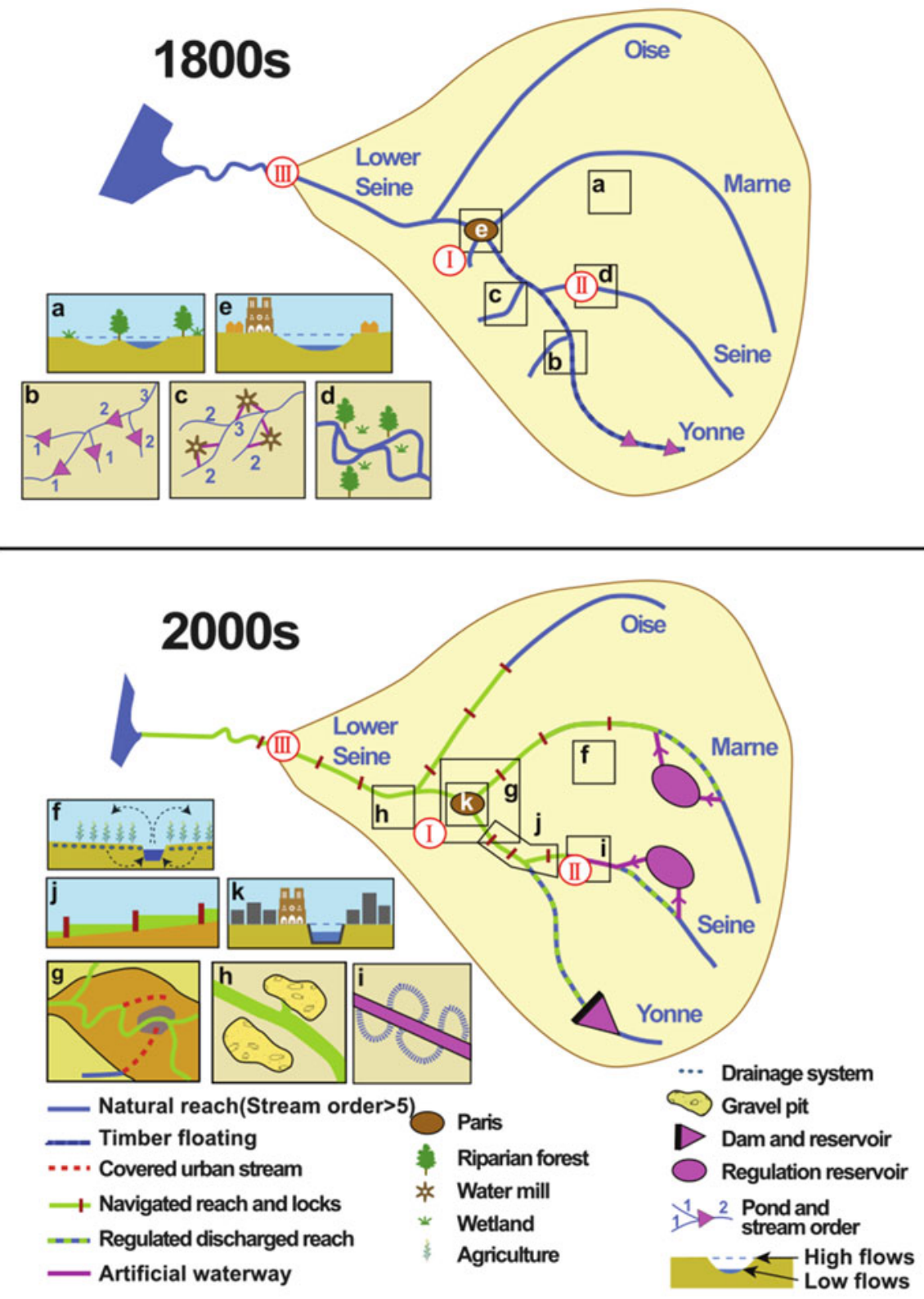

Fig. 1 Schematic presentation of the Seine River basin and its main tributaries (orders 6-7) with zooms on specific man-made physical transformations. Situation in the early 1800s: (a) unregulated plateau streams; (b) fish ponds (plateaus) and water storage ponds for timber rafting; (c) fixed water mills; (d) free meandering in alluvial plain (e.g. Bassée); (e) Seine within Paris city. Situation in the 2000s: (f) tile drains, irrigation and ditches in cropland; (g) deepened and/or covered urban and periurban rivers; (h) leftover water-filled sandpits in floodplains; (i) artificial navigation channel cut 
around 1800 with a total volume of $1-1.5 \mathrm{M}$ steres per year and declined rapidly after 1900. In the rest of the basin, other ponds, mostly for fish production, had been established on headwaters since the Middle Ages [25]. An analysis of Cassini's maps showed that, in the late 1700s, 2,550 ponds were present in the whole Seine catchment $\left(65,000 \mathrm{~km}^{2}\right)$, mostly on first-order streams (69\%) [26]. In some regions their density approached $0.5 / \mathrm{km}^{2}$ (Fig. 1b). Fish production was for local use (e.g. abbeys) or exported to nearby cities and more distant cities as Paris, via waterways. The impact of urban water demand on headwaters is fully documented for Versailles, which started to develop in 1663: the construction of the chateau and city involved a major diversion of stream waters (see Sect. 4, Fig. 5).

Fixed water mills were found on all stream orders, principally on orders 2-3 (Fig. 1c). They resulted in the partial diversion of streams through a new course with regulated slopes, ending with a small water fall $(0.5-1 \mathrm{~m})$, while the "old course" was mostly active at the high-water stage. Around Paris the mill density on small rivers was on average $0.5 / \mathrm{km}^{2}\left(6,000\right.$ over $\left.12,000 \mathrm{~km}^{2}\right)$ [27] or one mill per $5 \mathrm{~km}$ of river course. Within Paris and on navigated rivers, floating mills were established.

In the alluvial plain of the stream orders 3-4, an artificial network of ditches was used for centuries to flood grasslands when needed [25]. In greater floodplains (Fig. 1d), a few kilometres wide such as the Bassée (see below in case studies, Fig. 6), wetlands and riparian forest dominated. In these free-meandering lowlands, side arms of the main river, slack waters and abandoned oxbows were common; they were mostly activated and connected during major floods ( $>5$-year return period).

Stream orders 5-7 were generally navigated, which created a major regulatory difference with non-navigated reaches: the former were managed by the state, the others by local owners, a distinction that continues today [28]. These navigated rivers were not yet regulated, either concerning the water discharge or the river level (Fig. 1e), with the noted exception of the Yonne, used for timber rafting.

Many of the modifications of the river course were already generated by Paris's demand for goods, food, fuel wood and construction wood, largely transported by waterways. In 1800 Paris was already a metropolis located in the centre of the Seine basin, with $11 \%$ of the basin's total population ( $0.5 \mathrm{M}$ for a total of $4.5 \mathrm{M}$ inhabitants) [29], which relied heavily on the basin hinterland for food and energy [30]. However, the Seine River was not regulated and only slightly artificialised; banks were largely natural and sandy slopes were still used for landings (Fig. 1e).

During the Napoleon era, the state began to develop the navigation facilities on the Seine within Paris, with harbours, artificial banks and docks [31]. Numerous institutions were related to the river transport, particularly the state Ponts et Chaussées corps of engineers in charge of managing the state-owned navigated rivers, corresponding to orders 5-7.

Fig. 1 (continued) across floodplains; (j) navigated sectors with stable levels between locks; (k) regulated river level and artificial banks within the urban sectors. Case studies: I, Versailles plateau; II, Bassée alluvial plain; III, Poses lock and weir 


\subsection{Current State of the Seine River Water Bodies}

From 1830 to the present day, most of the water bodies of the Seine River have been physically modified, from the headwaters to the estuary. These changes have been gradual and planned for water resources management, navigation development, agricultural drainage, etc. (Fig. 1, lower part).

In the marl and limestone agricultural parts of the Seine basin (e.g. Beauce and Brie), the tile drainage of cropland reaches its maximum proportion (20-40\%) [23]. It has been developed since the nineteenth century by specific engineers and peaked between the 1960s and 1990s (Fig. 1f). Intensification of agriculture has also led to the transformation of some first-order streams into ditches. Meanwhile summer sprinkler irrigation was developed. As a result, the wetland area was reduced, and many order 1 streams are no longer in natural conditions, except in the forested parts of the basin. Most ponds along stream orders 1-3 have now been converted into cropland. The Morvan forest ponds linked to rafting have not been maintained.

Water mills are no longer in operation, but orders 2-4 often keep their heritage of side channels and weirs. Historical maps allow to connect these past river works to the river's cultural history, which gives them a patrimonial value, although they are now considered by the Water Framework Directive as fish obstacles and devices blocking the sediment transit of the river, which should be removed.

Small rivers around Paris (orders 2 and 3) have greatly suffered from urban sprawl: their lower parts have been covered and transformed into sewers and then into storm runoff sewers (e.g. Bièvre, southwest of Paris, and Croult, north of Paris) (Fig. 1g). Urbanisation also results in the water sealing of some parts of catchment surfaces and therefore to riverbed erosion related to peak discharges during heavy rains [32].

In the floodplain of the Middle and Lower Seine, as far as $150 \mathrm{~km}$ from Paris, demands for sand and ballast for construction of the expansion of Paris, new railways and a nuclear power plant in the Bassée resulted in the excavation, from 1950 to 2000, of dozens of sandpits, 10-100 ha wide, filled with alluvial groundwaters, 2-5 m deep, some connected with the main channel (Fig. 1h; see also Fig. 6). Given that the sandpit sedimentation rate is low to medium (less than $1 \mathrm{~cm} \mathrm{year}^{-1}$ ), the filling of these water bodies will take centuries.

In 1830-1840, the French state initiated a major effort to develop river transport management for the needs of Paris. The navigated reaches of the Seine, Marne and Oise rivers are those in which the river course has been completely modified in its three dimensions. The trajectory of the river works has been uniform for nearly 200 years: the navigation channel is now narrower; the course is straightened, particularly in floodplains, and equipped with dikes or levees (Fig. 1i); the channel is deeper and regularly dredged; the connection with floodplain water bodies is decreased; and the river banks are steep. This has resulted in a major change on these river reaches, with new types of river works, docks and weirs (Fig. 1j) termed recalibration by river engineers, a positive expression during this period of river 
taming and dedication of the river to human uses. These changes were made in several steps, corresponding to political decisions and technical innovations [33]. River reaches were mapped in three dimensions with great precision and accuracy prior to any construction works, leaving behind precious archives that are used today to access the initial river course morphology.

Until the 1940s, the river level within Paris was not regulated, and extreme low levels were observed in summer (Fig. 1k). In 1910, an exceptional event occurred: the flooding of Paris and its suburbs by a 100-year return period flood. Another phase of river management ensued. The new objective was to maintain the river level at a fixed value $\pm 35 \mathrm{~cm}$, with minimum river discharge variations [34]. Flood protection and low-water discharge regulation for Paris led to the creation of four main reservoirs, which were constructed in the 1930s-1980s on the Yonne, Upper Seine, Aube and Marne rivers (schematically represented in Fig. 1), some 250 river $\mathrm{km}$ upstream of Paris. These facilities, financed by the city of Paris, increased the summer low flows from $25 \mathrm{~m} \mathrm{~m}^{3} / \mathrm{s}$ (extreme value at Paris) up to $100 \mathrm{~m}^{3} / \mathrm{s}$, thus reducing the impact of the Paris region on the water quality of the Lower Seine.

When comparing the 1800 and 2000 figures, the weight of Paris on the Seine River course is enormous, considering the local and proximal changes such as the artificialisation of the river courses within Paris, the high regulation of discharge and the water level, the loss of many suburban river reaches or the modification of the water balance over the urbanised sectors. But Paris also controls the river in a distal mode, either upstream by the regulation reservoirs for flood protection and low-water enhancement or 100-250 km around Paris on regulated and navigated river reaches and by the sandpit excavation. Many of these river transformations can be documented with historical maps. Cartographic document analysis can also be complemented by other approaches to assess the slow longue durée evolution of the river, such as the use of former furnace slags to measure the very slow river bedload movement (Box 1).

\section{Box 1 Historical Slag Residues: Another Approach to Slow River Dynamics}

In lowland meandering rivers such as the Seine, riverbed transport is very slow and the deposited sand-gravel material might only move during medium rare to rare events. In these rivers with relatively low energy and therefore with low morpho-sedimentary adjustments, the impact of obstacles such as weirs, river mill diversions, small reservoirs and navigation sluices is relatively unknown.

Coarse sediment transport in the Seine basin occurs at a slow pace, which can be quantified by the analysis of slag residues from historical high-furnace iron smelting, even if mill weirs have temporarily or permanently interrupted or disturbed sedimentary transit for several centuries. 
Box 1 (continued)

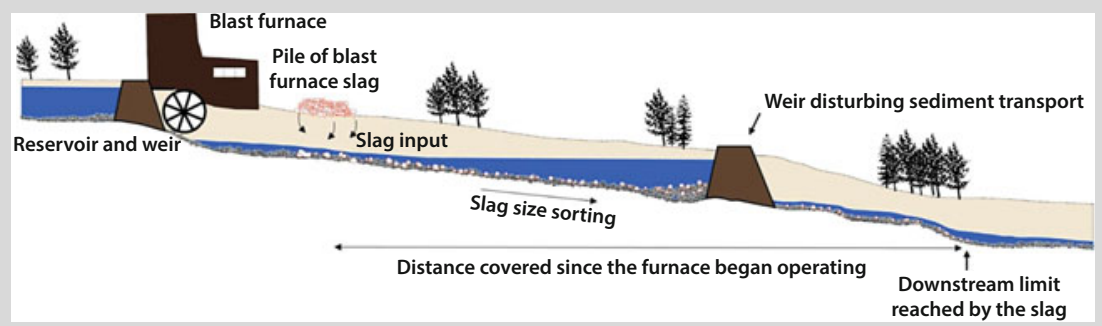

These small industries, using river power, were developed from sedimentary ore deposits in the Upper Marne region (Fig. 1), beginning in the fifteenth century until the early 1900s. From the knowledge of the injection site and its period of operation, by taking the largest slag present in the bed from upstream to downstream, we can assess the competence of the river and the rate of progression of the load background (see above). Their slag residues, of $\mathrm{cm}$ size, still found today in the river bed, have a density close to that of the natural gravel which characterises these upper basin reaches $\left(2.2-2.5 \mathrm{~g} / \mathrm{cm}^{3}\right.$ vs $2.6 \mathrm{~g} /$ $\mathrm{cm}^{3}$ ). It can be postulated that they are transported at the same rate as natural riverbed particles [35].

A specific field study carried out on the Rognon, a medium-sized tributary to the Upper Marne, downstream of a well-dated and well-located former blast furnace, gives a minimum gravel transport rate of only $2.16 \mathrm{~km} / 100$ years. Slag residues have been detected in a large number of streams in the Seine basin, which make it possible to determine which grain size particles are regularly transported through the watercourse and their velocity displacement, as well as the role of transverse obstacles on their displacement.

\section{Historical Maps: A Tool for Quantifying the Physical Changes of Water Bodies}

Historical cartographic documents, maps, charts, plans, river profiles and drawings are stored in archive depositories, generally within administrative services, in thousands of closed boxes, each containing a dozen of maps in average, that must be opened as the preliminary step of the research, followed by the extraction of their cartographic documents, their scanning and the recording of their related information (objectives, techniques, producers, etc.). Documents are then selected according to their scale, coverage, represented elements and then geo-referenced and all riverrelated elements (punctual, linear, surface) digitalised in a GIS. Finally, their analysis gives quantitative information on the state of the river and its associated water bodies and their dynamics, over the last two centuries (Fig. 2). Several fields of river 

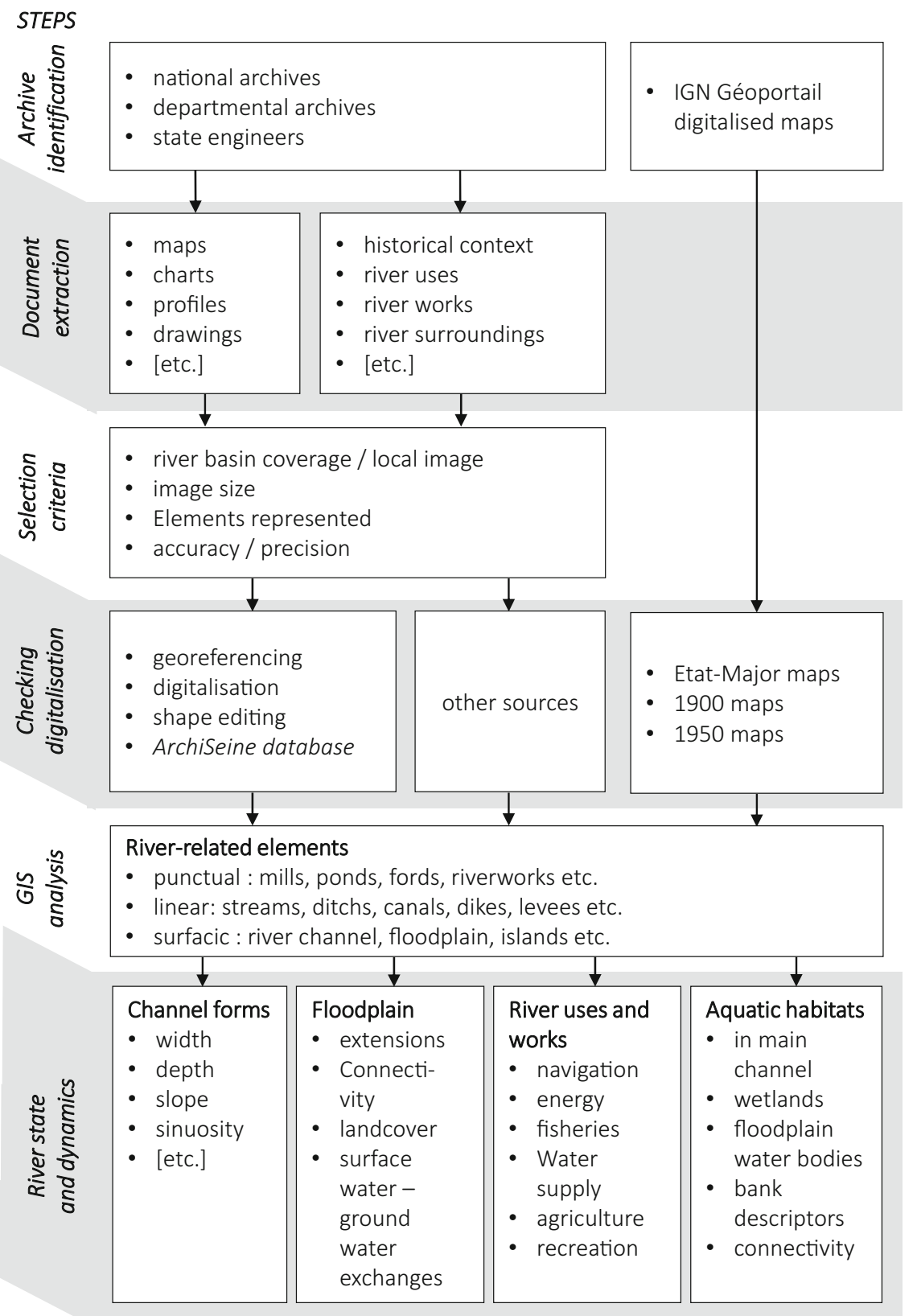

Fig. 2 Schematic steps of the analysis of historical cartographic documents on water bodies to quantify the their morphology, uses and water works as well as aquatic habitats and their dynamics 
research may benefit from this quantified spatial and temporal analysis: hydromorphology, hydro-ecology, socio-economic uses of the fluvial territory, river management and river restoration.

These treated documents related to rivers of the Seine basin were put in an openaccess database (ArchiSeine) (Box 2), which complements the Geoportail openaccess digitalised historical maps established by the IGN (Institut Géographique National).

The following section focuses on hydro-morphology, particularly for the navigated river channel. A brief overview of the history of the cartographic documents of the Seine River and their critical analysis is provided first.

\subsection{The Inventory and Critical Analysis of River Maps}

Historical cartographic documents provide area-wide information that is not available in classical archives. They give representations of river-related objects such as islands, river-land interfaces, hydrological networks, man-made infrastructures, river uses, river regulatory status, etc., as well as the territory (relief, pathways and villages) aside from the river network and its corridor.

In the 1700s maps had become an essential means of describing and understanding the territory and its evolution and an indispensable strategic and geopolitical instrument [36]. In France, Colbert's establishment in 1666 of the Royal Academy of Sciences allowed the development of cartographic methods, particularly triangulation by Jean Picard and then by a dynasty of cartographers founded by JeanDominique Cassini who achieved the first complete coverage of France at a scale of 1/86,400 in less than 100 years, from 1747 to 1818 , but the representation of rivers was not always accurate and insufficiently precise for further quantitative analysis.

\section{Box 2 ArchiSeine: An Open-Access Cartographic Database on River History}

In 2013 the PIREN-Seine program launched a joint project with the French National archives to identify, restore and digitalise historical maps, charts and drawings related to the Seine River and its major tributaries. From 1,000 documents already identified, covering a period from the end of the eighteenth century to the 1930s, and chartered by the state's Pont et Chaussées corps of engineers, one-third have already been geo-referenced and presented on the ArchiSeine website [37, 38]. Each document is supplemented by metadata providing its historical context (authors, institution, objectives, etc.).

These charts and drawings are mainly (1) local maps related to planned and/or completed river works and (2) large-scale maps or drawings related to complaints and other judiciary acts concerning river works. These documents 
Box 2 (continued)

have been complemented in the ArchiSeine data set by several maps directly related to the river course, such as the wood rafting map of the Seine River basin and charts published for commercial and recreational navigation.

Aside from ArchiSeine, three old general cartographic sets of France, now digitalised (IGN, Geoportail, https://www.geoportail.gouv.fr/. Accessed 15 May 2019), can be used for the quantitative analysis of the fluvial system and its evolution, from 1830 to 2015: the Etat-Major Map (1830-1860), the 1900 Map and the 1950 Map (Fig. 3). The Seine River basin is represented by dozens of sheets in each of these maps.

The second push for cartography was given by the creation of the Ponts et Chaussées corps of engineers, who were responsible for drawing up these maps. Progressively map status was transformed into a territorial management and decision-making instrument. For Verdier, this was "a profound mutation of cartography... for Ponts et Chaussées engineers, mapping was already part of solving a problem" [39]. These engineers also used standardised methods, initiated by Buchotte in the first specific cartographic manual published in France in 1722, for code colour by land use type or relief representation [40].

All land use and water use development projects were validated by Ponts et Chaussées technical advice, and the related maps were sent by engineers in each département and archived in the centralised Maps and Drawings Depository in the Ministry of Public Works, established under the First Empire [41]. The development of river navigation in 1830-1850 [33, 42,43] generated a great number of

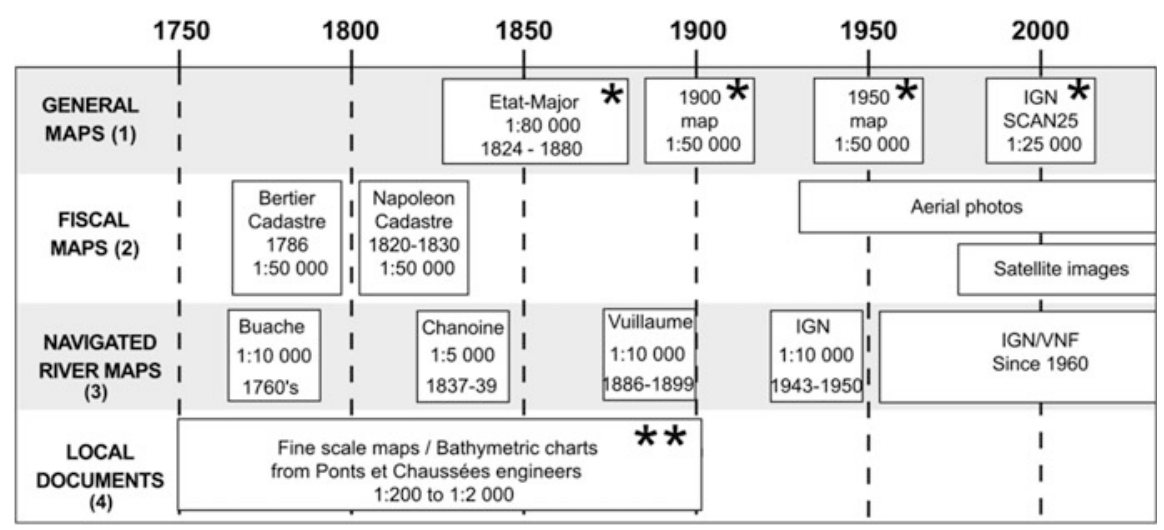

Fig. 3 Main sources of historical cartographic documents on the Seine River used in quantified trajectory analyses. 1 , General medium-scale mapping of the French territory; 2, general fine-scale mapping for raising taxes (land registry); 3, maps and charts produced by state engineers for navigated rivers; 4, other local documents and bathymetric profiles. * Open-access geo-referenced and digitalised documents available on IGN-Geoportail. ** ArchiSeine documents (see Box 2) 
cartographic and textual documents which fulfill the different criteria for potential quantitative analysis. Many documents drawn by river engineers present the original state of the river, prior to their planned works, as well as the future situation after the recalibration (rectification, dredging, dikes and levee construction): this data set can therefore be used to approach the natural conditions of the river channel of orders 5-7, which were not yet greatly affected by human activities (see Sect. 2). The 1910 flood which damaged Paris resulted in an exceptional depository of these documents in the national archives.

The Seine River basin is covered by a great variety of maps (Fig. 3), in terms of spatial coverage, from local to basin-wide $\left(65,000 \mathrm{~km}^{2}\right)$ spatial scales, extending over the last 200 years. In addition to the set of maps and drawings made by the Ponts et Chaussées engineers, one also finds the fine-scale land registry established for taxation purposes, such as the land registry supervised by Bertier [44], the Napoleonic Land Registry [45], or the Etat-Major Map $(1 / 50,000)$ drawn by the War Ministry (1840-1860s).

Navigation charts give numerous details on the river channels. The first ones were drawn from 1731 to 1766 by Philippe Buache (1700-1773), considered as the first French geographer [46] (see Fig. 4c). They illustrate the many navigation difficulties (shoals, rocks) encountered on the Lower Seine reach, before the implementation of the first river management structures [42, 47]. The 19th July 1837 Law for navigation improvement on the Seine led to the drawing of the Seine River by Ponts et Chaussées engineers and the construction of the first set of six locks on the Seine River. Another set of charts was made between 1886 and 1899 by Raoul Vuillaume, the director of a new magazine dedicated to recreational navigation, Le Yacht (see Fig. 4e). These charts will be continued by institutions in charge of the navigation as the Seine Navigation Service (SNS, today Voies Navigables de France, VNF) and published by the IGN after the Second World War.

Around 2000 a major break in map production was observed stemming from the new GIS technology and its related on-line geo-referenced multiple data layers and the digitalised historic aerial photographic sets, which acquisition started before WWII. Finally, LIDAR coverage is now widely used to check the validity and accuracy of maps.

\subsection{General Use of Maps to Document River Environmental Changes}

Cartographic fluvial elements are very diverse (Table 1). Figure 4a-e presents a selection of these elements from maps of various origins and periods. Each of them provides specific information on the state of the river system at a given period and its potential changes in hydro-morphology, ecology, hydrology, aquatic resources, river uses and bio(geo)-chemical functioning. It is noteworthy that this state is the result of 

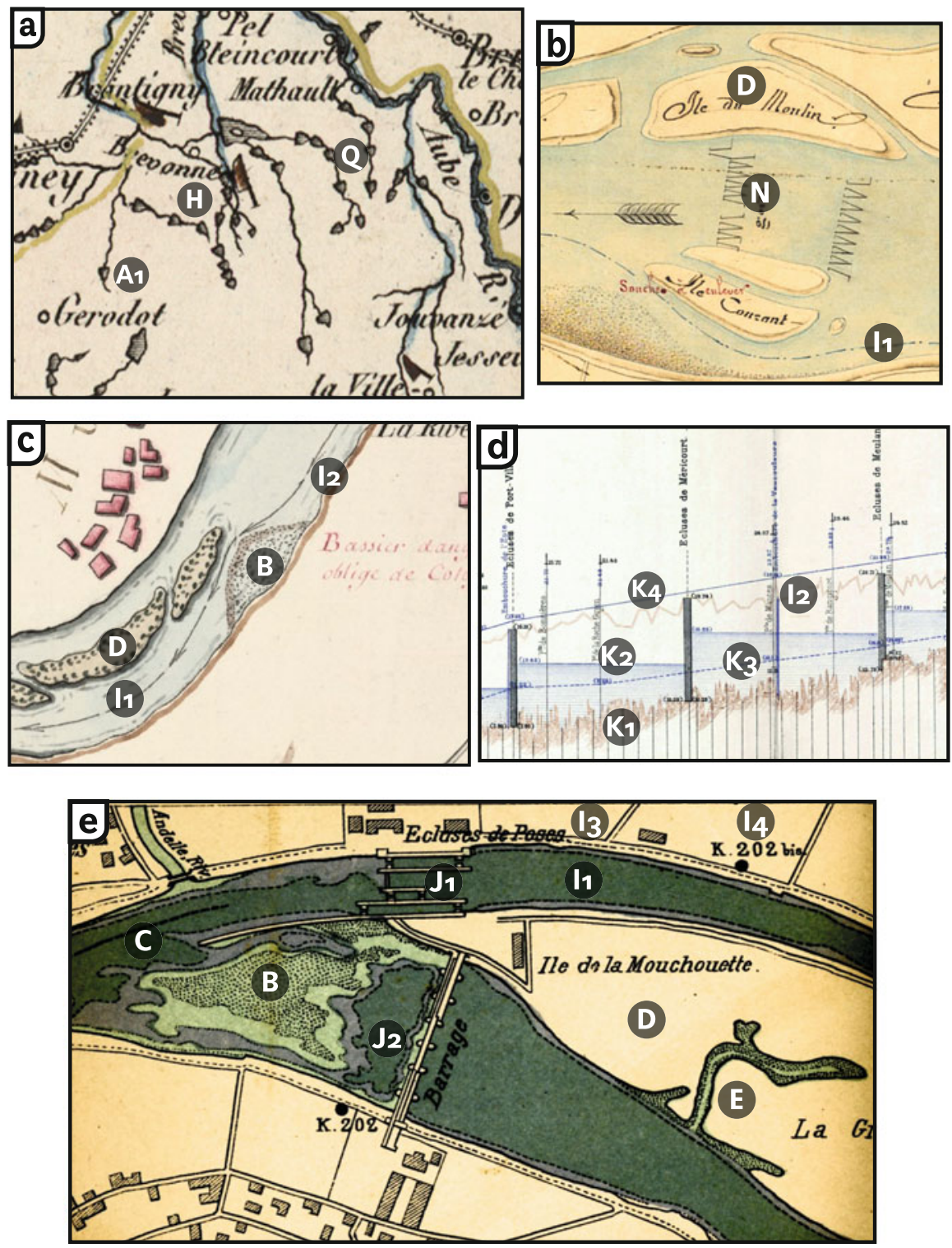

Fig. 4 Examples of fluvial elements represented on historical maps and listed in Table 1 (A-Q). (a) Timber rafting in 1828: ports $(\mathrm{H})$, ponds $(\mathrm{Q})$, first-order stream (A1) [Source: AN CP/F/14/10078, file 1, 67a]. (b) Fisheries on the Seine River in 1843 (N), islands (D), navigation channel (I1) [AN F/ 14/6577, file 5, 4]. (c) Shoals (B), towpath (I2) in 1766 on a Buache map [AN CP/F/14/10078, file 1, 2 h]. (d) 1883 River profile by Lagrené and Caméré: river bed (K1), regulated level (K2), low-water stage (K3), high-water stage (K4) [AN CP/F/14/10078, file 2, 51a]. (e) Lock (J1) and weir (J2), isobaths (C), disconnected channel (E), dikes (I3) and navigation mark (I4) in 1899 on a Vuillaume navigation map [Musée de la Batellerie et des voies navigables] 


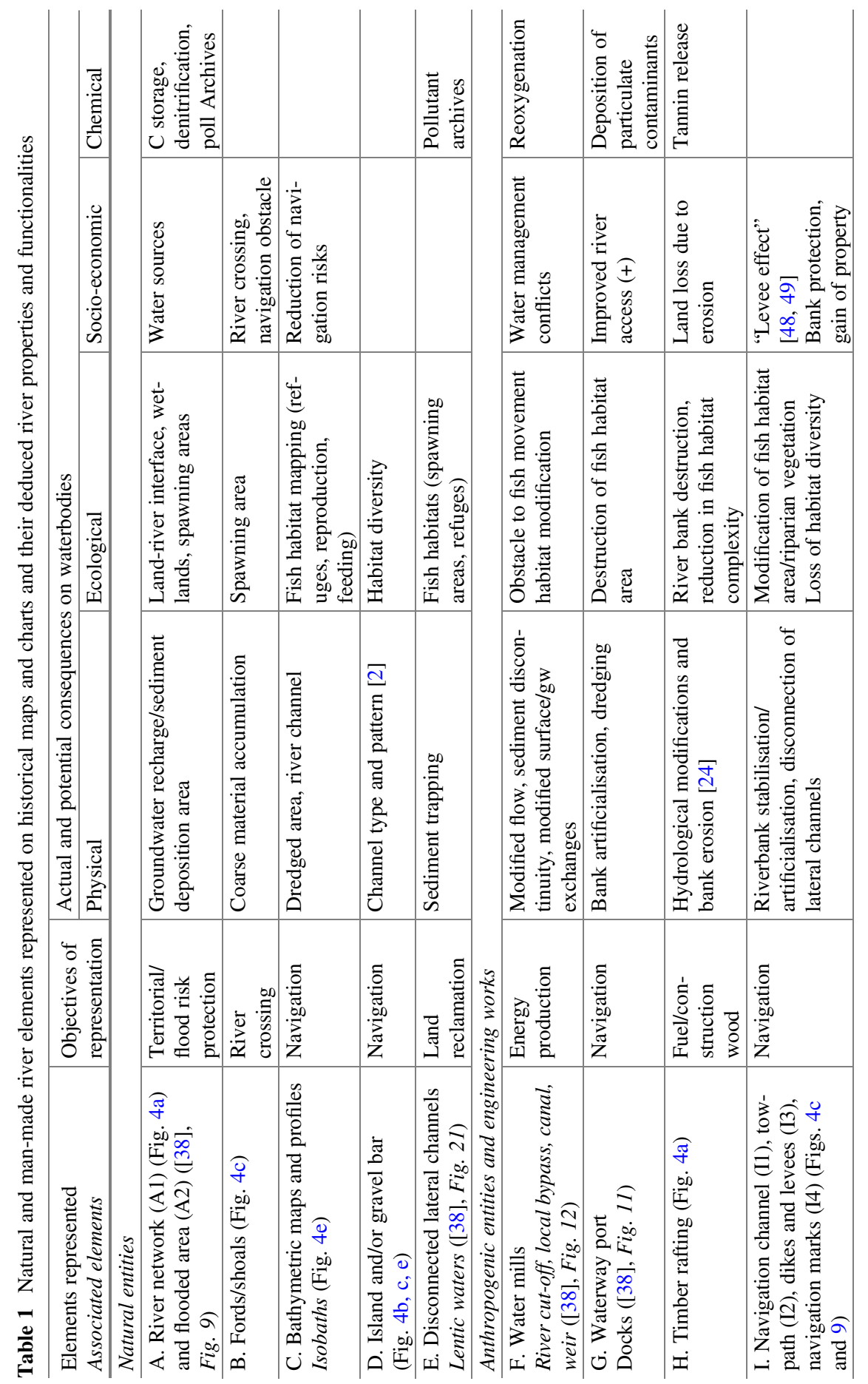




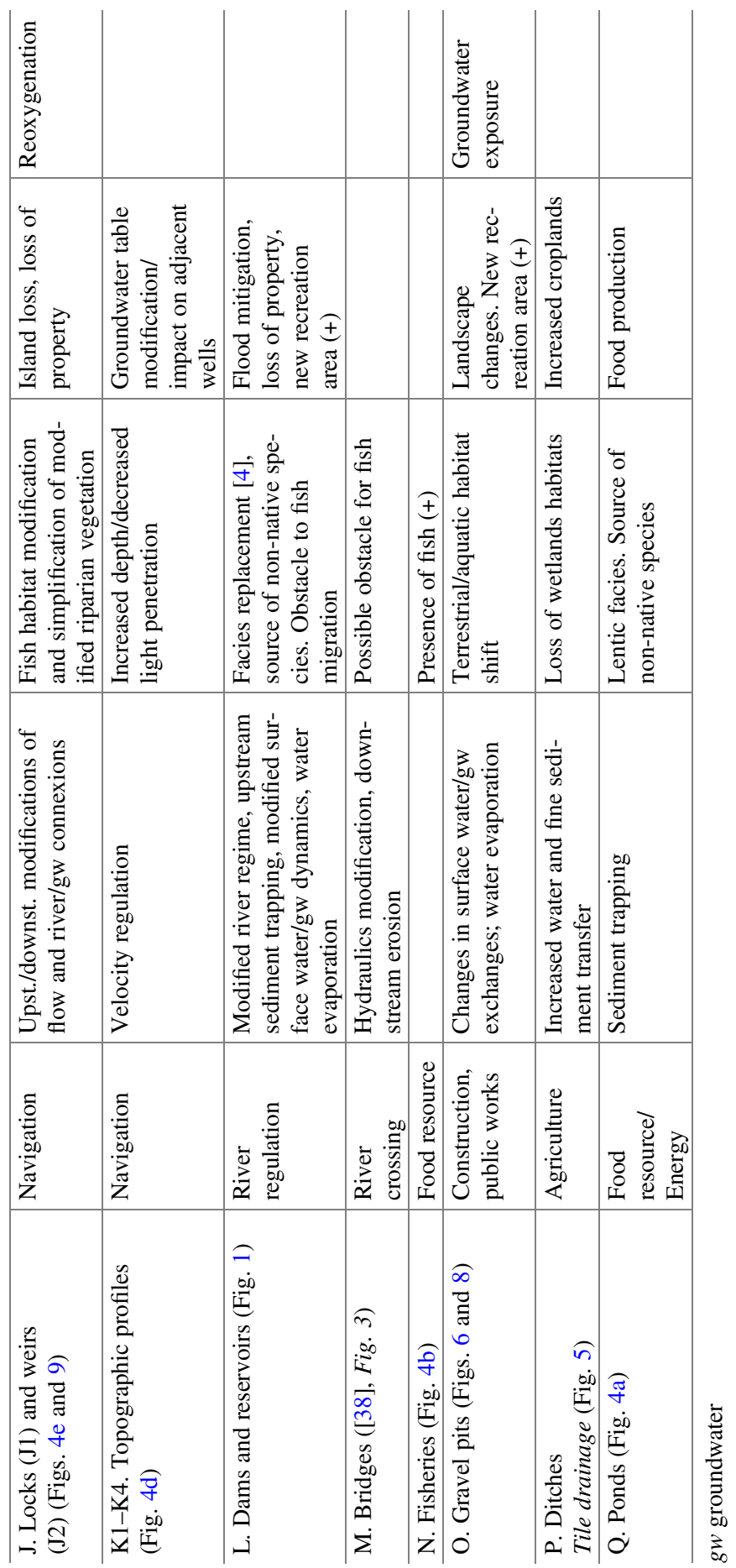


the cumulated natural and man-made transformations that have shaped the territory: any map reflects heritages of past dynamics.

Many natural (Table 1, A-E) and man-made (F-Q) elements were represented for navigation purposes, river network (A1) (see Fig. 4a) and navigation channel (I) (Fig. 4b, c, e), river depth (C) and topographic profiles (K) (Fig. 4d), obstacles (B, D, Fig. 4c), harbours (G) and locks (J) (Fig. 4e), or for river regulation, dams (L) or flooded area (A2). Other maps show places where energy is produced (water mills, F) or ponds $(\mathrm{Q})$ and starting areas for timber rafting $(\mathrm{H})($ Fig. 4a), elements related to agriculture (ditches on very-fine-scale maps (P), Fig. 5) and food production (fisheries, N, Fig. 4b).

The physical river state and dynamics can be studied on numerous elements: identification of channel type and pattern from the presence and shape of the islands [4], modified flows (watermill derivations on a lateral canal $(0.1-1 \mathrm{~km}$ ) while the main river course is left active only at high flows) and changes in river regime by dams and weirs; dredging area (navigation channel and ports); loss of lateral connectivity due to the artificialisation of the banks and raising them to create towpaths; modified groundwater/surface water exchanges due to the change in the river's water level (dams and weirs) and to the presence of gravel pits (O); bank erosion in timber rafting reaches [24]; and sediment trapping within reservoirs (L), disconnection of lateral channels (E), delineation of flooded areas (A2) and ponds (Q).

The ecological state of the river can be addressed particularly through its fish habitats. Presence of islands (D), disconnected lateral channels and oxbows (E) provides potential refuges, spawning grounds and feeding grounds for fish [2]. The deepening of the river and the bank re-profiling seen on bathymetric maps (C) (e.g. Vuillaume, Fig. 4e) result in the loss of fish habitat areas and diversity. Dams (L), water mills (F) and weirs (J) are obstacles to fish migration. In the 1890s, weirs on the Lower Seine (Fig. 4d, e) were equipped with fish ladders, but they were not sufficiently effective to allow salmon, once common in the Seine basin $[50,51]$, to reach their spawning grounds $400 \mathrm{~km}$ upstream in the basin headwaters. The connectivity and the ecology of fluvial wetlands are also affected by river works, mainly dikes and levees (I) and more recently by sandpits.

The socio-economic uses of the river, the potential water conflicts and the flood risks can be analysed from river maps: the river network (A1) shows where to access surface water resources; water mills (F) mark where river power was used and potential water conflicts; navigation and river access are facilitated by river works; but new reservoirs $(\mathrm{L})$ or erosion areas $(\mathrm{H})$ result in loss of property. In contrast, river channeling (I) and the related disconnection/filling of backwater wetlands lead to a possible gain of property for the riparian landowners. Dikes and levees (I) were considered until recently as effective protection against flooding, leading to economic development close to the river. This positive "levee effect" ([48], Cited by [49]) is now being revised $[49,52,53]$ because, although dikes prevent the natural inundation of the floodplain, they also limit the water storage at high flows and therefore increase the flood risk for downstream settlements.

Finally, some chemical effects on rivers can be related to fluvial elements represented on maps. Water mills $(\mathrm{F})$, dams (L) and weirs (J) have downstream 
reoxygenation effects but upstream deoxygenation in the reservoirs, which are also more affected by eutrophication. Timber rafting $(\mathrm{H})$ may release tannins. Gravel pits expose groundwaters to contamination. Docks, disconnected lateral channels and flooded areas (A2) are areas of pollutant storage which can be analysed to reconstruct former pollution levels and trends [54].

In addition, the comparison of successive maps provides insights into the dynamics of the fluvial system (Table 2). Examples of these dynamics and the methodology for quantifying these changes are provided in Sect. 4.

This diachronic analysis can be performed through planimetric (surface evolution) or vertical (depth evolution) comparisons (Sect. 4.2). The river network and the river channel can be completely modified, from the smallest stream orders, whose modification can lead to changes in the shape and size of the catchment area (Sect. 4.1 ), to the channelised river where many transformations can be demonstrated by comparing maps: the disappearance or modification of islands, often to facilitate navigation (Sect. 4.3), the so-called channel rectification, the channelisation by engineering works and the resulting channel adjustments, i.e. its natural evolution following an engineering structure downstream or upstream.

The comparison of maps also provides information on the evolution of land use in the catchment areas and the possible impact of this evolution on the physical attributes of the rivers, for instance, the evolution of agriculture towards more intensive practices, especially in first-order streams, which can lead to conflicts for water use, the appearance of gravel pits in the alluvial plain which modify its hydraulics (Sect. 4.2) or the waterproofing of urban soils, which results in the "urban stream syndrome", i.e. an increase of rain storm runoff, and riverbed erosion $[32,55]$.

Ecological responses to changes in fluvial dynamics can be assessed through changes in river fish habitat distribution. They can range from immediate (effect of damming on fish migration) to decadal (effects of minor bed deepening on the floodplain groundwater dynamics and its ecology).

Visualising and quantifying these changes can also help to understand the conflicts reported in the archives, such as water resource problems, property conflicts or increased flood risks.

\section{Historical Trajectories of Selected Water Bodies in the Seine River Basin}

The application of the use of historical maps is illustrated here through three examples: (1) Versailles plateau headwaters (stream orders 1-3), (2) Bassée floodplain (order 6) and (3) the Poses sector (order 7), which marks the limit between the Lower Seine and the fluvial estuary. All case studies show a pronounced human impact on the natural river system in the last 200-300 years. 
Table 2 Quantitative dynamics of the fluvial system and its uses retrieved from the comparison of historical maps

\begin{tabular}{|c|c|c|c|}
\hline Compared elements & Physical dynamics & Ecological dynamics & $\begin{array}{l}\text { Socio- } \\
\text { economic } \\
\text { issues }\end{array}$ \\
\hline $\begin{array}{l}\text { First-order stream } \\
\text { capture (Fig. 5) }\end{array}$ & Basin size and shape & & $\begin{array}{l}\text { Water } \\
\text { resources } \\
\text { imbalance }\end{array}$ \\
\hline $\begin{array}{l}\text { Island modification } \\
\text { (levelling, attach- } \\
\text { ment to banks) } \\
\text { (Fig. 9) }\end{array}$ & Local flow acceleration & $\begin{array}{l}\text { Loss of habitat } \\
\text { diversity }\end{array}$ & $\begin{array}{l}\text { Navigation } \\
\text { improvement }\end{array}$ \\
\hline $\begin{array}{l}\text { Man-made channel } \\
\text { correction (Figs. } 6, \\
7 \text { and 9) }\end{array}$ & $\begin{array}{l}\text { Disconnection of secondary } \\
\text { arms (hydraulic decoupling) }\end{array}$ & $\begin{array}{l}\text { Loss of linkages } \\
\text { between rivers and } \\
\text { floodplains; loss of } \\
\text { rearing habitat }\end{array}$ & $\begin{array}{l}\text { Modification } \\
\text { of flood risks }\end{array}$ \\
\hline $\begin{array}{l}\text { River channel } \\
\text { adjustment (Fig. 8) }\end{array}$ & $\begin{array}{l}\text { Channel responses, lateral ero- } \\
\text { sion or aggradation after river } \\
\text { works }\end{array}$ & $\begin{array}{l}\text { Changes in river habi- } \\
\text { tat distribution }\end{array}$ & $\begin{array}{l}\text { Changes in } \\
\text { land property }\end{array}$ \\
\hline $\begin{array}{l}\text { Bathymetric pro- } \\
\text { files (reported on a } \\
\text { altitudinal } \\
\text { landmark) }\end{array}$ & $\begin{array}{l}\text { Erosion zones (incision), } \\
\text { changes in water level, dredg- } \\
\text { ing impacts }\end{array}$ & $\begin{array}{l}\text { Dried riparian vegeta- } \\
\text { tion. Loss of habitat } \\
\text { diversity }\end{array}$ & $\begin{array}{l}\text { Modification } \\
\text { of flood risks }\end{array}$ \\
\hline $\begin{array}{l}\text { Agricultural inten- } \\
\text { sification (soil } \\
\text { crustability } \\
\text { enhancement) }\end{array}$ & $\begin{array}{l}\text { Increased storm runoff, } \\
\text { gullying }\end{array}$ & & $\begin{array}{l}\text { Competition } \\
\text { between } \\
\text { water users }\end{array}$ \\
\hline $\begin{array}{l}\text { Evolution of gravel } \\
\text { pits (Fig. 7) }\end{array}$ & $\begin{array}{l}\text { Exchanges between ground- } \\
\text { water table and river }\end{array}$ & & $\begin{array}{l}\text { Groundwater } \\
\text { exposure to } \\
\text { pollution }\end{array}$ \\
\hline $\begin{array}{l}\text { Land use change in } \\
\text { urban area (soil } \\
\text { impermeabilisation) }\end{array}$ & $\begin{array}{l}\text { Increase of rain storm runoff, } \\
\text { riverbed erosion ("urban } \\
\text { stream syndrome" [55]; } \\
\text { increased flow variability) }\end{array}$ & $\begin{array}{l}\text { Artificialisation of river } \\
\text { habitat }\end{array}$ & \\
\hline
\end{tabular}

\subsection{Stream Network Modification on the Versailles-Saclay Plateau (1670-1860)}

The Versailles plateau, situated $50 \mathrm{~km}$ west of Paris, is one of the earliest and best documented examples of urban impacts on local streams (see location on Fig. 1). The Versailles château, its gardens and fountains, and its homonymous city were constructed in the late seventeenth century. At that time, the region was devoid of major water resources, and the Sun King mandated his engineers to supply his properties from two main water sources, (1) the famous Marly Machine, which elevated the Seine River water (Fig. 5), and (2) the derivation of all headwaters of the Saclay and Rambouillet plateaus to Versailles instead of flowing to the Yvette or Bièvre river, through a complex network of dugout ponds, ditches and aqueducts, 


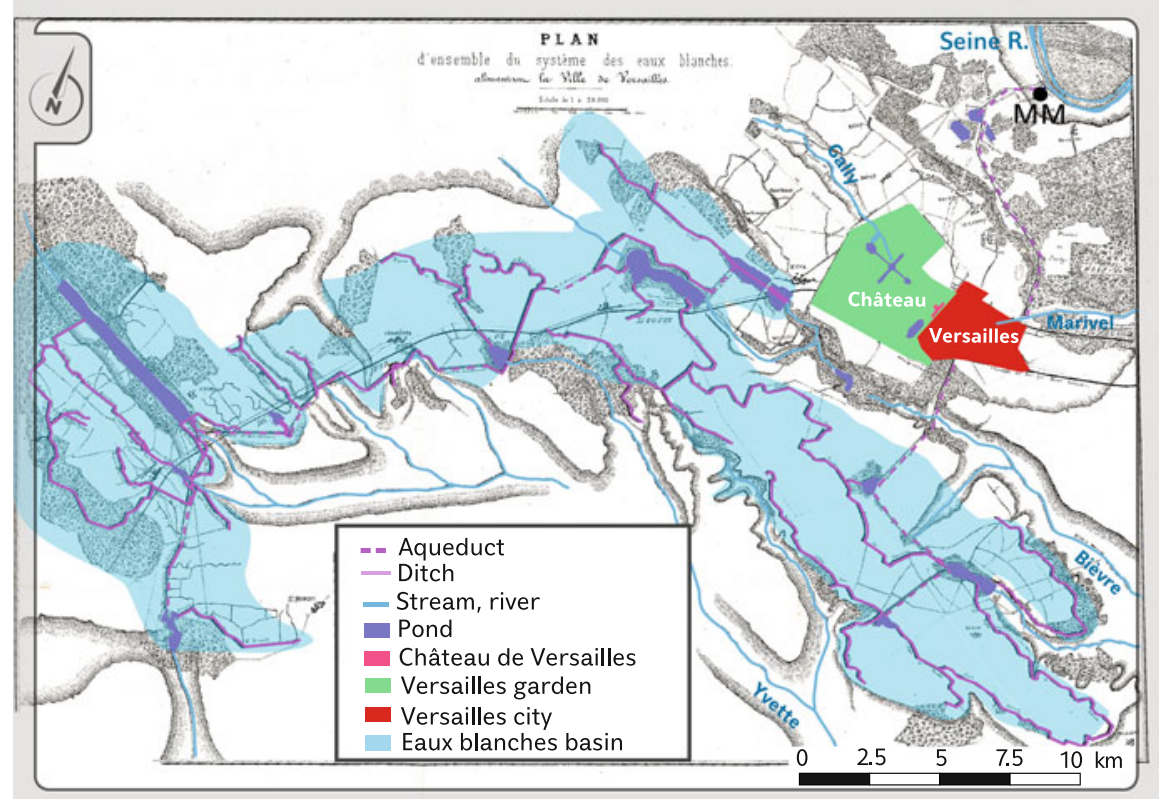

Fig. 5 Modifications of the headwater stream networks on the Versailles-Saclay plateaus to supply water to the Versailles chateau, fountains and city beginning in 1670 . Digitalised networks of the 1861 map by La Vallée. MM, Marly Machine network of aqueducts and reservoirs using Seine River waters; blue and violet, Eaux Blanches networks on the plateau

the so-called Eaux Blanches (white waters), in operation for 290 years. The water supply map of 1861 by La Vallée illustrates these derivations, totalling $135 \mathrm{~km}$ in length and covering $192 \mathrm{~km}^{2}$. The discharge of the $\mathrm{Ru}$ de Gally, the first-order stream which starts in the Versailles Gardens, was in turn multiplied by a factor of three given that it received all waste waters from the chateau and city, untreated until the 1950s [56].

\subsection{Man-Made Heterogeneity of the Floodplain: Channelisation and Sandpits in the Bassée Floodplain}

The Bassée alluvial plain is the major wetland of the Seine basin and stands in the Seine valley upstream of the Seine/Yonne confluence (see location in Fig. 1).

Archive sources show that sporadic river channel works were already undertaken in this sector before the 1600 s to improve navigation and timber rafting [57]. In the second half of the nineteenth century, waterway transport was again promoted by the construction of dikes and then navigation canals, some $10 \mathrm{~km}$ long, excavated across the floodplain as the Beaulieu-Villiers canal (1885) and the Bray-La Tombe canal 


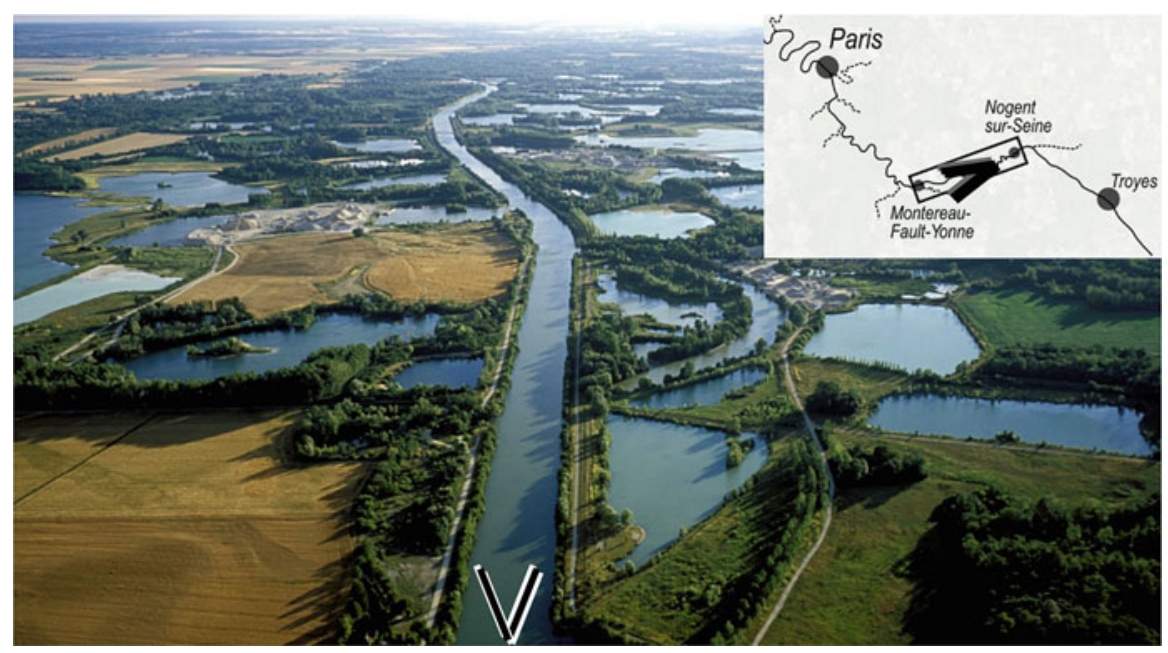

Fig. 6 Aerial photograph of the Bassée floodplain, upstream of the Seine-Yonne confluence, showing the multiple sandpits, generally filled by groundwaters, and the straightened, deepened and dredged navigation channel with its levees and dikes. A former river meander part, now a disconnected water body, is visible on the right centre of the picture. Only patches of the original riparian forest remain between the sandpits and the agricultural areas [ $\odot$ La Pérouse 2005]

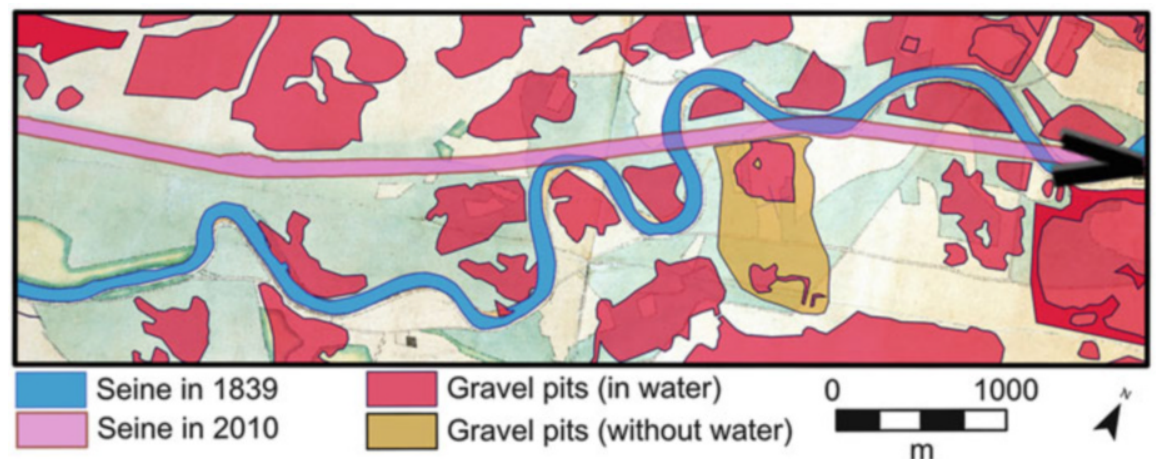

Fig. 7 Example of the Bassée floodplain transformations between 1839 and 2010, showing the dominance of man-made water bodies (pink $=$ Grand Gabarit canal and red = sandpits) on a 6-km-long river sector (same sector as Fig. 6). Black arrow shows the point of view of the aerial photograph (Fig. 6)

(1899). The latter was abandoned in 1979, when the so-called Grand Gabarit canal (4.8 m draught) cut across the lower Bassée from La Grande Bosse to Montereau (Fig. 6).

In the 1970 s, the hydrological dynamics of the Bassée were also impacted by the operation of two large reservoirs (Aube and Seine Reservoirs; see Fig. 1): the low 
flows are now artificially increased to sustain the summer water discharge in Paris, some 150 river km downstream, by a factor 3-4.

Figure 7 shows the evolution of the Seine River and the adjacent alluvial plain as depicted on a map from 1839 compared to the current situation, in the same area as that shown in Fig. 6. This 1/5000 1839 map covers a portion of the Bassée floodplain between Nogent-sur-Seine and Montereau-Fault-Yonne, $43 \mathrm{~km}$ long, 3-5 km wide, totalling 14,828 ha. It was drawn by the engineers of the Ponts et Chaussées in preparation for the first phase of the river works in this sector. The current situation is recorded on the $1 / 25,000$ Scan 25 C map of the IGN.

In this sector of the Bassée, one can observe the Grand Gabarit canal which has cut across the original meandering river course and created artificial and/or re-profiled bank. Today the Bassée is still a major wetland sector, according to the EU definition, but the riparian forest, its oxbows and other types of wetlands have been transformed by dozens of sandpits, some of which, still in operation, are not yet under water.

The accuracy of the 1839 map [58] quantifies slow changes of the Seine River as the secular natural meandering dynamics (Fig. 8). This map was drawn up as follows: (1) GIS geo-referencing; (2) identification and listing of the common spot, linear and surface elements; (3) digitalisation of these elements; (4) superimposition of these cartographic elements across time; and (5) determination of the many metrics (position, perimeter, length, area, etc.) and their temporal evolution $[38,58]$. The rectification of the Seine in the whole Bassée led to a decrease in the length of the thalweg from 66.7 to $63.0 \mathrm{~km}$. At the same time, the bed of the Seine was deepened and the average width of the Seine River decreased from 79.2 to $59.4 \mathrm{~m}$. The meander shift rate of the natural Seine River was around $5 \mathrm{~m} / 100$ years

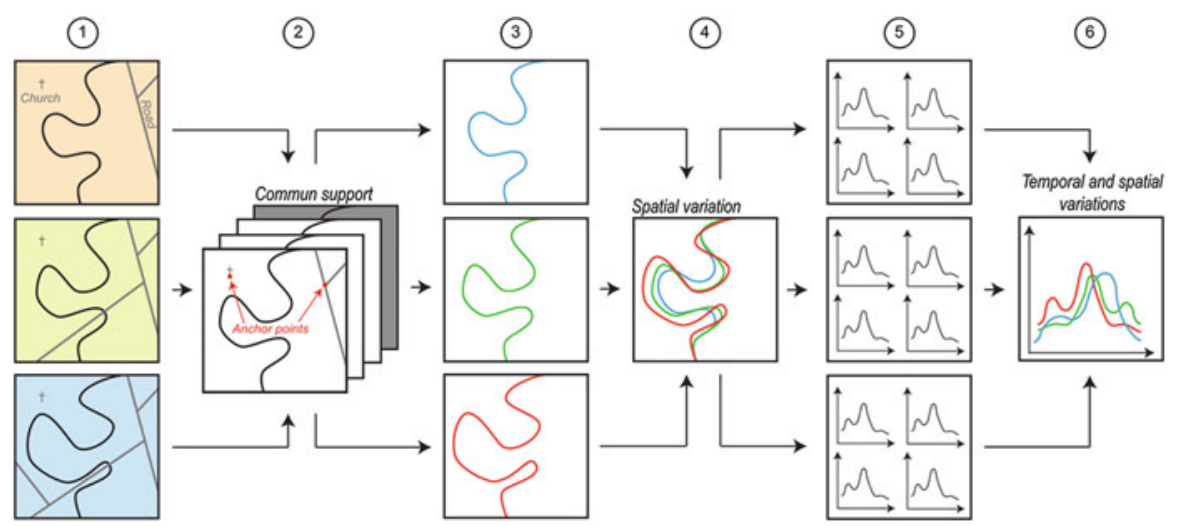

Fig. 8 Methodological approach for the processing and analysis of cartographic archives concerning river courses. Simplified diagram, adapted from the treatment chain developed by [59]. 1 Compilation of successive maps for the same sector; 2 scaling, geo-referencing; 3 digitalisation; 4 qualitative analysis (visualisation of lateral changes); 5 quantitative analysis (sinuosity, width, length, etc.); 6 spatio-temporal interpretation of fluvial changes 
between 1839 and the middle of the twentieth century, thus illustrating the slow dynamic of the Seine River here [2].

From the 1950s onwards, the Bassée alluvial plain was exploited as gravel pits, with an average of 37 ha transformed into gravel pits every year since then (BRGM, 1995). They are typically between a few hectares and 100 ha (Fig. 6), a few metres deep, and most of them are filled with waters from the alluvial aquifer, which is found between 0.5 and $1.25 \mathrm{~m}$ from the ground level in most locations [21].

Between 1839 and 2010, the waterscape of the Bassée was completely transformed: in 1839, the natural Seine River channel covered 400 ha, and other bodies contributed 70 ha. In 2010, the artificial navigated channel covered 340 ha, the former river channels and associated natural waterbodies 360 ha and the waterfilled sandpits 1,783 ha. As a whole, the open waterbody coverage of this sector has been increased five times. This tendency will continue in the near future with the construction of artificial water storage compartments, totalling 2,300 ha for the whole project, to store river water when Paris and its suburbs, some 100 river $\mathrm{km}$ downstream, are threatened by inundation. Ten compartments are planned, separated by $58 \mathrm{~km}$ of artificial dikes, up to $4.7 \mathrm{~m}$ high (http://www.seinegrandslacs.fr/leprojet-global-damenagement. Accessed 15 May 2019).

As a whole, this natural major wetland has been severely transformed for navigation (channel rectification), for construction (gravel pits) and in the future for flood control purposes (artificial water storage compartments): the mosaic of former natural water bodies, flooded forest and wetlands has been replaced by another mosaic of artificial water bodies, navigation channels and sandpits, with greater depths, often steep slopes, limited aquatic vegetation and direct exposure of the phreatic aquifer (which may result in a deterioration of the quality of groundwater used for drinking water supply). In the last 25 years, efforts have been made to "renaturalise" these artificial waterbodies, particularly as bird refuges.

\subsection{Simplification of Seine River Channel and Loss of Islands}

In the last 200 years, the navigation on the Seine River has resulted in simplification and deepening of the channel and regulation by locks. River map archives also show that simultaneously most islands have been reconnected to the banks. Between the 1830s and today, 405 islands have been reconnected along the $340 \mathrm{~km}$ river course from the Seine-Yonne confluence to Rouen in the Seine estuary [60]. The history of these islands, their settlements and uses, is rarely told in classical archives as these parts of the river area are seldom inhabited [61].

The cartographic archives, along with historical information on navigation structures, can be used to reconstruct their history. Figure 9 shows the modifications of the river channel in the Poses sector (for location, see Fig. 1), which marks today's upper limit of the tidal influence, between 1846 (Ponts et chaussées map) and 2015 (IGN map). 


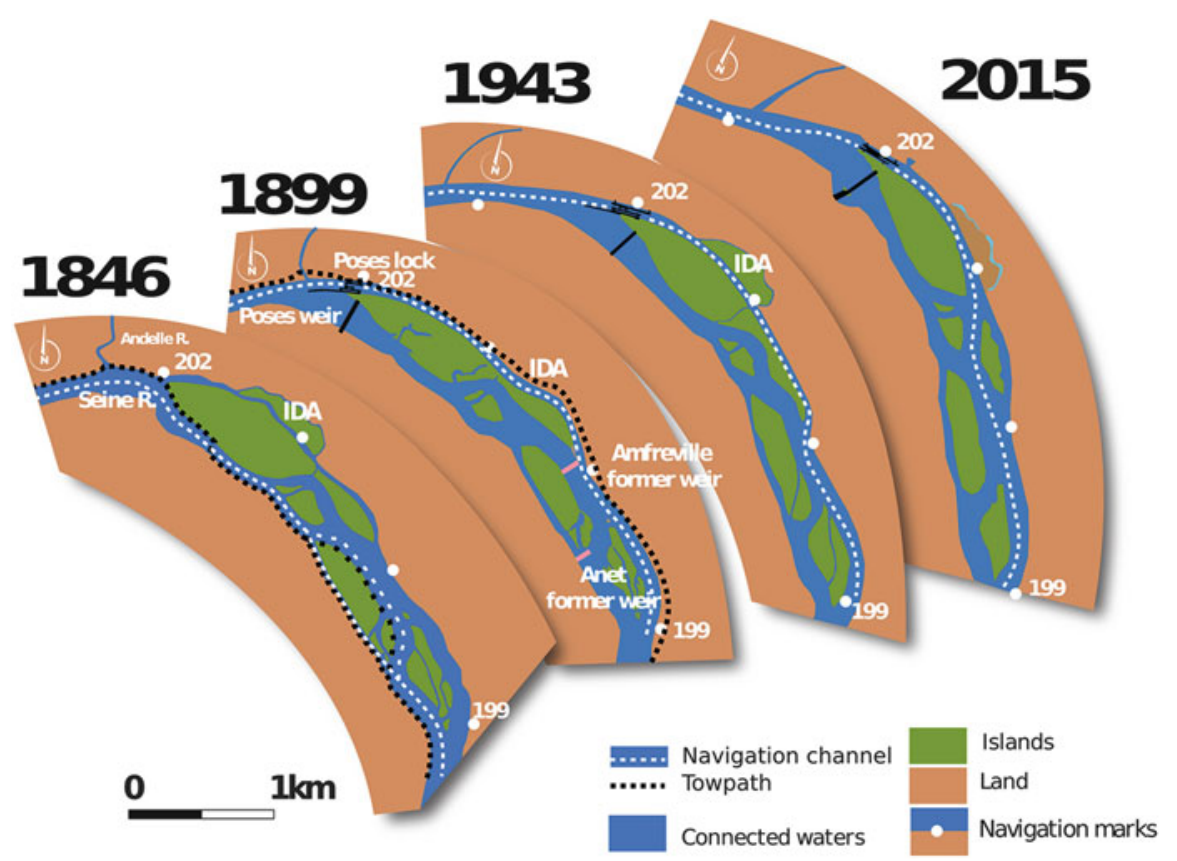

Fig. 9 Evolution of the Seine River course from geo-referenced and digitalised cartographic documents (1846-2015), showing the trajectories of river morphology and islands, towpath and navigation channel. Current navigation marks (I4), each river km downstream of Paris, are used as points of reference. IDA Ile des Deux Amants [37]

In 1846, Ile des Deux Amants Island (Fig. 9, IDA) was already reconnected to the right bank. Then its toponym rapidly disappeared from maps. The towpath in the Poses sector reveals, within a few kilometres, a complex shift between the banks and numerous islands, which implied complex manoeuvres of men and horses two or four times across the river. In 1852 the first Poses weirs and locks (Amfreville and Anet) were established. The navigation time between Rouen and Paris was accordingly shortened [42]. In 1886, the locks were moved downstream to Poses. In 1899 the Vuillaume map shows the fusion of several islands and the simplification of the navigated channel. The 1943 state is based on the navigation map published by IGN. The aerial photos (Geoportail, IGN) show that the islands upstream of the locks were separated in 1963-1964, to create a new navigation channel. Poses weir was again rebuilt in 1967, resulting in a drop of the water level between 5.4 and $8 \mathrm{~m}$, depending on the tidal amplitude. This weir was considered as the essential obstacle to migratory fish circulation, such as salmon, lampreys, sea trout and shad (Alosa alosa) until the installation of two fish ladders in 1991 and 2018 to facilitate the upward circulation of these fishes.

These changes in island configuration were essentially anthropogenic and cannot be assumed to result from sediment supply increase - e.g. by enhanced erosion of agricultural areas - as featured in the Schumm diagram [2, 4]. Here, the islands were 
often merged by the disposal of materials, dredged in the navigation channel, in a non-navigated arm.

These island modifications had multiple consequences: the relatively still waters, used as resting areas, refuges during floods, spawning grounds and/or fishing grounds for some fish species have decreased. The total length of river banks per kilometre of river course has also markedly decreased (around 30\% between the 1880s and 2010) as well as river habitat heterogeneity.

\section{Conclusion and Perspectives}

In Western European rivers, physical changes have affected the lower and medium stream orders since the Middle Ages, and sometimes earlier, as demonstrated by archeo-geology [3]. The heritage of these slow and gradual changes, and the related cultural elements (mills, ponds, etc.), has been represented with accuracy and precision since the early 1800 s in various cartographic documents.

The selected cartographic documents mainly represent the visions that engineers had on these areas at each period, particularly on the fluvial area. But they can also be used to reconstruct, within our contemporary knowledge and technical means, the longue durée evolution of the river and stream network, the river channel in its three dimensions - longitudinal, lateral and vertical - and its related floodplain and the river-related natural and cultural elements represented. Our contemporary interpretations of these documents must be cautious: the reliability of these ancient documents must be assessed. The context and the objective of the cartographic work must be established, with its quality, accuracy, imprecision and relevance with regard to the contemporary research objectives [62].

These well-contextualised cartographic documents were used to perform quantified geo-historical analyses through two main approaches: (1) the analysis of the state of the river at a given period and (2) the comparison of two states, which provides the dynamics of the elements represented.

The applications of the analysis of historical cartographic documents are numerous: they can be used to investigate hydro-morphology, hydro-ecology, water resources and river use history, as well as river restoration and management. These natural and/or human-made changes lead to new hydraulic and hydrodynamic conditions which eventually reshape the river course and the aquatic environment, as evidenced by the evolution of the morphometric parameters. In turn the aquatic biota readapts to these new conditions. In the case of river works, the most frequent one, the related adjustments provide the response times of the aquatic environment to the pressures exerted on them. As these responses are often on the decadal or multidecadal scale, analysis of cartographic archives is essential.

The physical modifications documented here have been found for every stream order, from the headwaters (e.g. Versailles plateau, Morvan forest) to the riverestuary limit (Poses sector, order 7). Several drivers are responsible for these 
existing and planned physical modifications of the fluvial system, thus shaping its trajectories:

Urban development, perfectly documented since the seventeenth century for Versailles chateau, gardens and city, results in major transformations of stream orders $1-3$. In the nineteenth and twentieth centuries, the spatial and demographic expansion of Paris and its surroundings have also generated major changes in medium-sized urban streams (orders 2-4) [17].

The intensification of agriculture has largely modified first-order streams, converted into ditches to which underground tile drains are connected.

The intensification of navigation has been continuous since 1830, resulting in multiple transformation of the river channel in orders 5-8. It is largely driven by the urban development of Paris and by the export of agricultural products from the Seine basin. This activity is still progressing.

The demand for sand and gravels, extracted from the Seine, Marne and Oise floodplains, has been generated by urban and infrastructure development after 1950 and has reshaped the landscape of the alluvial plains.

River flow regulation and flood security have already resulted in the construction of large reservoirs able to double or triple the natural Seine River flow at Paris in summer and reduce the flood stage. New water storage facilities are now planned in the Bassée floodplain, finalising the physical transformation of the major wetland of the Seine Basin, already impacted by sandpits and river channelisation.

Unlike many pollutions caused by the Paris region, which have decreased or have been treated since 1960 or 1970 (see the following chapters), the physical modifications of the river network, channel and floodplain, and of its related habitats that have taken place in the last 200 years, are mostly irreversible, at least for order 5-7 rivers.

Today, many actors - river and water users, decision-makers and citizens - have a stake in the balance between river biodiversity and good ecological state, flood risk control, recreational uses and economic uses: some of these uses control the rivers' future, others react and adapt. For these reasons, the Seine River basin and its society is a typical example of a territory in the Anthropocene era, where society has gradually and permanently controlled a major part of the natural system [63]. Aside from physical control, other examples of biochemical, chemical or ecological controls are presented and illustrated in the following chapters.

Further applications of this work, which has required the identification of numerous archives over the past 8 years, during the previous phases of the PIREN-Seine programme, already include the evolution of obstacles to migratory fish and the identification of sediment archive storage sites to reconstruct trajectories of contaminants in the Seine basin [54]. One may also consider integrating the vertical evolution of the channel into the groundwater/surface water exchange models (see [64]). When focusing on the socio-economic and ecological consequences of river evolution, we can see that the entire extent of alluvial plains is in fact impacted. Specific studies, based on the same methodology of quantitative analysis of historical maps, will be carried out in the next phase of the PIREN-Seine project (2020-2023) to describe trajectories of the river corridor as a whole. 
Acknowledgements This work is a contribution to the PIREN-Seine research programme (www.piren-seine.fr), which belongs to the Zone Atelier Seine part of the international LongTerm Socio-Ecological Research (LTSER) network. ArchiSeine is the result of a work carried out within a convention between the PIREN-Seine research programme and the French National Archives.

\section{References}

1. Bravard JP, Piegay H (2000) L'interface Nature - Sociétés dans les hydrosystèmes fluviaux. Géocarrefour 75(4):273-274

2. Amoros C, Petts GE (1996) Hydrosystèmes fluviaux. Chapman and Hall, London

3. Lespez L (2012) Paysages et gestion de l'eau: sept millénaires d'histoire des vallées et des plaines littorales en Basse-Normandie. Presses University, Caen

4. Downs PW, Gregory KJ (2004) River channel management: towards sustainable catchment hydrosystems. Arnold, London

5. Gurnell AM, Piery JL, Petts GE (2003) Using historical data in fluvial geomorphology. In: Kondolf M, Piégay H (eds) Tools in fluvial geomorphology. Wiley, Chichester

6. Jacob-Rousseau N (2009) Géohistoire/géo-histoire: quelles méthodes pour quel récit ? Géocarrefour 84(4):211-216

7. Bravard JP (2010) La valorisation de la cartographie historique des rivières d'Europe, de la recherche sur la dynamique des paysages à la gestion des eaux. In: Masotti L (ed) Il paesaggio dei tecnici, Attualità della cartographia storica per il governo delle acque. Marsiolio, Bolognia

8. Robert S (2011) Sources et techniques de l'archéogéographie planimétrique. Presses Universitaires de Franche-Comté, Besançon

9. Braga G, Gervasoni S (1989) Evolution of the Po river: an example of the application of historical maps. In: Petts GE, Möller H, Roux AL (eds) Historical change of large alluvial rivers: Western Europe. Wiley, Chichester, pp 113-126

10. Bravard JP, Gaydou P (2015) Historical development and integrated management of the Rhône River floodplain, from the Alps to the Camargue Delta, France. In: Hudson PF, Middlekoop H (eds) Geomorphic approaches to integrated floodplain management of lowland fluvial systems in North America and Europe. Springer, New York, pp 289-320

11. Hohensinner S, Lager B, Sonnlechner C et al (2013) Changes in water and land: the reconstructed Viennese riverscape from 1500 to the present. Water History 5(2):145-172

12. Arnaud F, Piégay H, Schmitt L et al (2015) Historical geomorphic analysis (1932-2011) of a by-passed river reach in process-based restoration perspectives: The Old Rhine downstream of the Kembs diversion dam (France, Germany). Geomorphology 236:163-177

13. Cioc M (2002) The Rhine, an eco-biography, 1815-2000. University of Washington Press, Seattle/London

14. Mauch C, Zeller T (eds) (2008) Rivers in history. Perspectives on waterways in Europe and North America. University of Pittsburgh Press, Pittsburgh

15. Castonguay S, Evenden M (2012) Urban rivers. Remaking rivers, cities, and space in Europe and North America. University of Pittsburgh Press, Pittsburgh

16. Knoll M, Lübken U, Schott D (2017) River lost, rivers regained. Rethinking city-river relations. University of Pittsburgh Press, Pittsburgh

17. Lestel L, Carré C (eds) (2017) Les rivières urbaines et leur pollution. Quae, Paris

18. Petts GE, Möller H, Roux AL (1989) Historical change of large alluvial rivers: Western Europe. Wiley, Chichester

19. Gregory KJ (2006) The human role in changing river channels. Geomorphology 79 (3-4):172-191 
20. Mouchel JM, Boet P, Hubert P et al (1998) Un bassin et des hommes: une histoire tourmentée. In: Meybeck M, de Marsily G, Fustec E (eds) La Seine en son bassin. Elsevier, Paris, pp 77-125

21. Fustec E, Greiner I, Schanen O et al (1998) Les zones humides riveraines: des milieux divers aux multiples fonctions. In: Meybeck M, de Marsily G, Fustec E (eds) La Seine en son bassin. Elsevier, Paris, pp 211-262

22. Bendjoudi H, Weng P, Guérin R et al (2002) Riparian wetlands of the middle reach of the Seine river (France): historical development, investigation and present hydrologic functioning. A case study. J Hydrol 263(1):131-155

23. Guerrini MC, Mouchel JM, Meybeck M et al (1998) Le bassin de la Seine: la confrontation du rural et de l'urbain. In: Meybeck M, de Marsily G, Fustec E (eds) La Seine en son bassin. Elsevier, Paris, p 29

24. Poux AS, Gob F, Jacob-Rousseau N (2011) Reconstitution des débits des crues artificielles destinées au flottage du bois dans le massif du Morvan (centre de la France, XVIe-XIXe siècles) d'après les documents d'archive et la géomorphologie de terrain. Geomorphologie 17 (2):143-156

25. Rouillard J, Benoit P, Morera R (2011) L'eau dans les campagnes du bassin de la Seine avant l'ère industrielle, vol 10. PIREN-Seine, Paris. Available via PIREN Seine. https://www.piren-seine.fr/ fr/content/l'eau-dans-les-campagnes-du-bassin-de-la-seine-avant-l'ère-industrielle. Accessed 15 May 2019

26. Passy P, Garnier J, Billen G et al (2012) Restoration of ponds in rural landscapes: modelling the effect on nitrate contamination of surface water (the Seine watershed, France). Sci Total Environ 430:280-290

27. Boët P, Belliard J, Berrebi D, Thomas R et al (1999) Multiple anthropogenic impacts induced by Paris on fish populations in the Seine Basin, France. Hydrobiologia 410:59-68

28. Le Sueur B (2015) Le domaine public des rivières et de canaux. Histoire culturelle et enjeux contemporains. L'Harmattan, Paris

29. Flipo N, Lestel L, Labadie P et al (2020) Trajectories of the Seine River basin. In: Flipo N, Labadie P, Lestel L (eds) The Seine River basin. Handbook of environmental chemistry. Springer, Cham. https://doi.org/10.1007/698_2019_437

30. Billen G, Barles S, Garnier J et al (2009) The food-print of Paris: long-term reconstruction of the nitrogen flows imported into the city from its rural hinterland. Reg Environ Chang 9(1):13-24

31. Guillerme A (1990) Le testament de la Seine/the legacy of the Seine. Géocarrefour 65 (4):240-250

32. Jugie M, Gob F, Virmoux C et al (2018) Characterizing and quantifying the discontinuous bank erosion of a small low energy river using structure-from-motion photogrammetry and erosion pins. J Hydrol 563:418-434

33. Cotte M (2002) L'amélioration de la navigation sur les rivières françaises au XIXe siècle: le cas de la Haute-Seine et de l'Yonne. In: Hilaire-Pérez L, Massounie D, Serna V (eds) Archives, objets et images des constructions de l'eau du Moyen Âge à l'ère industrielle. SFHST, ENS éditions, Paris, pp 265-279

34. Barles S (2015) The main characteristics of urban socio-ecological trajectories: Paris (France) from the 18th to the 20th century. Ecol Econ 118:177-185

35. Houbrechts G, Levecq Y, Vanderheyden V et al (2011) Long-term bedload mobility in gravelbed rivers using iron slag as a tracer. Geomorphology 126:233-244

36. Harley JB, Gould P, Bailly A et al (1995) Le Pouvoir des cartes: Brian Harley et la cartographie. Anthropos, Paris

37. ArchiSEINE. Site d'archives et de données historiques sur le bassin versant de la Seine. http:// archiseine.sisyphe.jussieu.fr/site/. Accessed 15 May 2019

38. Lestel L, Eschbach D, Steinmann R et al (2019) ArchiSEINE: une approche géohistorique du bassin de la Seine, vol 18. PIREN-Seine, Paris. Available via PIREN Seine. https://www.pirenseine.fr/fr/fascicules/archiseine-une-approche-géohistorique-du-bassin-de-la-seine. Accessed 15 May 2019 
39. Verdier N (2009) Les plans et cartes du XIXe siècle. Introduction. In: Costa L, Robert S, Foucault M (eds) Guide de lecture des cartes anciennes. Illustrations dans le Val d'Oise et le Bassin parisien. Errance, Paris, pp 7-9

40. Buchotte (1722) Les règles du dessein et du lavis. Chez Claude Jombert, Paris

41. Archives Nationales (2009) Etat général des fonds. F/14. Travaux publics. http://www. archivesnationales.culture.gouv.fr/chan/chan/series/pdf/F14-2011.pdf. Accessed 15 May 2019

42. Merger M (1994) La canalisation de la Seine (1838-1939). La Seine et son histoire en Ile-deFrance, Paris et Ile-de-France Mémoires, vol 45. Editions du CTHS, Paris, pp 107-124

43. Beyer A (2016) Les grands jalons de l'histoire des voies navigables françaises. Pour mémoire. halshs-01664447

44. Touzery M, Ladurie ELR (1995) Atlas de la généralité de Paris au XVIIIe siècle: un paysage retrouvé. Comité pour l'Histoire économique et financière, Paris

45. Costa L, Robert S, Foucault M (2009) Guide de lecture des cartes anciennes: illustrations dans le Val d'Oise et le Bassin parisien. Errance, Paris

46. Lagarde L (1987) Philippe Buache, ou le premier géographe français, 1700-1773. Mappemonde 2:26-30

47. Coic J, Duleau A (1830) Reconnaissances de la Seine, de Rouen à Saint-Denis, en 1829 et 1830, et travaux proposés pour rendre cette partie de la Seine facilement navigable. Paris

48. White GF (1945) Human adjustments to floods, Department of Geography Research, Paper no. 20, 29, University of Chicago

49. Di Baldassarre GD, Viglione A, Carr G et al (2013) Socio-hydrology: conceptualising humanflood interactions. Hydrol Earth Syst Sci 17(8):3295-3303

50. Belliard J, Beslagic S, Delaigue O et al (2018) Reconstructing long-term trajectories of fish assemblages using historical data: the Seine River basin (France) during the last two centuries. Environ Sci Pollut R 25(24):23430-23450

51. Belliard J, Beslagic S, Tales E (2020) Changes in fish communities of the Seine Basin over a long-term perspective. In: Flipo N, Labadie P, Lestel L (eds) The Seine River basin. Handbook of environmental chemistry. Springer, Cham. https://doi.org/10.1007/698_2019_380

52. Guerrin J, Bouleau G (2014) Remparts ou menaces? Trajectoires politiques de l'endiguement en France, aux Pays-Bas et aux Etats-Unis. Rev Int Polit Comp 21(1):89-109

53. Auerswald K, Moyle P, Seibert SP et al (2019) HESS opinions: socio-economic and ecological trade-offs of flood management-benefits of a transdisciplinary approach. Hydrol Earth Syst Sci 23(2):1035-1044

54. Ayrault S, Meybeck M, Mouchel JM et al (2020) Sedimentary archives reveal the concealed history of micropollutant contamination in the Seine River basin. In: Flipo N, Labadie P, Lestel L (eds) The Seine River basin. Handbook of environmental chemistry. Springer, Cham. https:// doi.org/10.1007/698_2019_386

55. Walsh CJ, Roy AH, Feminella JW et al (2005) The urban stream syndrome: current knowledge and the search for a cure. J N Am Benthol Soc 24(3):706-723

56. Dmitrieva T, Lestel L, Meybeck M et al (2018) Versailles facing the degradation of its water supply from the Seine River: governance, water quality expertise and decision making, 1852-1894. Water History 10(2-3):183-205

57. Dzana JG (1997) Le lit de la Seine de Bar à Montereau: étude morphologique et rôle des aménagements. Thèse de doctorat en géographie, University of Paris 1, Paris

58. Eschbach D, Lestel L (2018) Dynamique hydromorphologique historique de la Seine dans le secteur de la Bassée aval. PIREN Seine report. https://www.piren-seine.fr/sites/default/files/ PIREN_documents/phase_7/rapports_annuels/2016/a2b4_Eschbach_PIREN_2018.pdf. Accessed 6 August 2019

59. Miramont C, Jorda M, Pichard G (1998) Évolution historique de la morphogenèse et de la dynamique d'une rivière méditérannéenne: l'exemple de la moyenne Durance (France du sud-est). Geogr Phys Quatern 52(3):381-392 
60. Lescure S, Arnaud-Fassetta G, Cordier S (2011) Sur quelques modifications hydromorphologiques dans le Val de Seine (Bassin Parisien, France) depuis 1830: quelle part accorder aux facteurs hydrologiques et anthropiques? EchoGéo 18:15

61. Charbit M (2016) Îles de la Seine. Edition du Pavillon de l'Arsenal, Paris

62. Grosso E (2010) Integration of historical geographic data into current geo-referenced frameworks: a user-centered approach. Proceedings of the 5th international workshop on digital approaches in cartographic heritage (Vienna 2010), pp 107-117

63. Meybeck M, Lestel L (2017) A Western European River in the Anthropocene. The Seine, 18702010. In: Kelly JM, Scarpino P, Berry $\mathrm{H}$ et al (eds) Rivers of the anthropocene. University of California Press, Oakland, pp 84-100

64. Flipo N, Gallois N, Labarthe B et al (2020) Pluri-annual water budget on the Seine basin: past, current and future trends. In: Flipo N, Labadie P, Lestel L (eds) The Seine River basin. Handbook of environmental chemistry. Springer, Cham. https://doi.org/10.1007/698_2019_ 392

Open Access This chapter is licensed under the terms of the Creative Commons Attribution 4.0 International License (http://creativecommons.org/licenses/by/4.0/), which permits use, sharing, adaptation, distribution and reproduction in any medium or format, as long as you give appropriate credit to the original author(s) and the source, provide a link to the Creative Commons licence and indicate if changes were made.

The images or other third party material in this chapter are included in the chapter's Creative Commons licence, unless indicated otherwise in a credit line to the material. If material is not included in the chapter's Creative Commons licence and your intended use is not permitted by statutory regulation or exceeds the permitted use, you will need to obtain permission directly from the copyright holder.

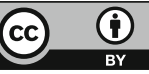

